\title{
Nodavirus in farmed Atlantic cod Gadus morhua in Norway
}

\author{
Sonal Patel ${ }^{1}$, Kjetil Korsnes ${ }^{1,2, *}$, Øivind Bergh ${ }^{1,3}{ }^{,}$Frode Vik-Mo ${ }^{4}$, Jan Pedersen ${ }^{1}$, \\ Audun Helge Nerland ${ }^{1}$
}

\author{
${ }^{1}$ Institute of Marine Research, PO Box 1870 Nordnes, 5817 Bergen, Norway \\ ${ }^{2}$ Bodø University College, 8049 Bodø, Norway \\ ${ }^{3}$ University of Bergen, Dept of Biology, PO Box 7800, 5020 Bergen, Norway \\ ${ }^{4}$ Bergen Fish Health Service, Bredalsmarken 15, 5006 Bergen, Norway
}

\begin{abstract}
Viral encephalopathy and retinopathy (VER) was diagnosed in 5 to $24 \mathrm{~g}$ sized farmed Atlantic cod Gadus morhua kept in sea cages at Parisvatn, Hordaland county, on the west coast of Norway. Moderate mortality (10 to $15 \%$ ) was observed, along with anorexia and abnormal swimming behaviour, such as looping or spiral swimming and reduced coordination. Nodavirus was detected by 2 different real-time RT-PCR assays, and this was later confirmed by immunohistochemistry. This is the first report of an outbreak of VER in farmed cod in Norway, and the first report that VER affect cod exceeding $5 \mathrm{~g}$ in size.
\end{abstract}

KEY WORDS: Nodavirus - Norway $\cdot$ Viral encephalopathy and reitinopathy $\cdot$ VER $\cdot$ Viral nervous necrosis $\cdot$ VNN $\cdot$ Atlantic cod · Gadus morhua

\section{INTRODUCTION}

Farming of Atlantic cod Gadus morhua is a growing industry in Norway, and in 2005 a total of 7410 metric tons ( $\mathrm{t}$ ) were produced (Directorate of Fisheries, Norway). This represents an approximately 40 -fold increase since 2000 (169 t), demonstrating a rapid growth in the farmed volume for this species. As intensive cultivation of cod is fairly new, the growth potential is estimated to increase sharply worldwide, and the largest growth is predicted to take place in Norway (Kjesbu et al. 2006). However, a major concern is the impact of diseases, as gadoid fish in culture are known to suffer from a variety of infectious diseases (Bricknell et al. 2006, Samuelsen et al. 2006). In particular, bacterial diseases such as vibriosis, atypical furunculosis and infections with Francisella sp. have been reported (Nylund et al. 2006, Olsen et al. 2006). The disease viral encephalopathy and retinopathy (VER) or viral nervous necrosis (VNN) is also reported to have caused mortali- ties in cod in Scotland (Starkey et al. 2001) and North America (Johnson et al. 2002). A small non-enveloped virus (25 to $40 \mathrm{~nm}$ ) belonging to the family Nodaviridae (Mori et al. 1992, Nishizawa et al. 1995) causes VER. This virus is reported to cause mortalities in a wide range of marine fish species worldwide (Munday et al. 2002). Nodavirus and outbreaks of VER have previously been reported in Norway, in juveniles of turbot Scophthalmus maximus suffering from encephalomyelitis (Bloch et al. 1991, Johansen et al. 2004) and in Atlantic halibut Hippoglussus hippoglossus (Grotmol et al. 1995, 1997, Aspehaug et al. 1999). Until now, these have been the only fish species reported to suffer from this disease in the Norwegian aquaculture industry. In Norway, VER is listed as a notifiable.

In August 2006, VER was diagnosed in farmed Atlantic cod (weight ranging from 5 to $24 \mathrm{~g}$ ) at a marine growth site in Parisvatn, Norway. The present paper describes the clinical observations and detection of nodavirus in this disease outbreak. 


\section{MATERIALS AND METHODS}

The affected Gadus morhua cod originated from broodstock previously transported from Austevoll $\left(60^{\circ} 05^{\prime} \mathrm{N}, 05^{\circ} 16^{\prime} \mathrm{E}\right)$ (Hordaland, Norway) to Parisvatn $\left(60^{\circ} 37^{\prime} \mathrm{N}, 04^{\circ} 48^{\prime} \mathrm{E}\right)$, Hordaland county, on the west coast of Norway (Fig. 1) in December 2005. Eggs were hatched in tanks in March 2006 and, shortly thereafter, transferred to a semi-enclosed marine ecosystem (Blom et al. 1991). The fish were dip-vaccinated against Listonella (vibrio) anguillarum, and in June 2006, 520000 juveniles of $2 \mathrm{~g}$ were transferred to sea cages at a marine growth site situated in close proximity to the marine ecosystem. At the time of sampling, the fish density in the sea cages was $3.3 \mathrm{~kg} \mathrm{~m}^{-3}$, and a commercial diet (Skretting, Norway) was fed ad libitum to the fish daily. The sea temperature was 18 to $19^{\circ} \mathrm{C}$, and the majority of the fish weighed from 5 to $10 \mathrm{~g}$.

Sampling. Fish were sampled in August and September 2006, and a total of 25 individuals were investigated. Only fish showing clinical signs of disease were sampled. Necropsies were performed, tissues were sampled for bacteriology (10 fish) and virus detection was carried out by real-time RT-PCR (15 fish). The real-time RT-PCR detections included sampling of 10 brains (medulla oblongata) from diseased cod in August and 5 individuals in September for which the tissues sampled were extended to include gills, ventricle, spleen, kidney, liver, eye and brain (medulla oblongata). All tissues were stored at $-80^{\circ} \mathrm{C}$ prior to molecular analysis. In March 2007, 5 additional cod showing clinical signs of VER were sampled for immunohistochemistry (IHC) analysis. Tissues included in IHC consisted of brain and eye.

Immunohistochemistry. Tissue samples were fixed in $4 \%$ phosphate-buffered saline (PBS) formalin, dehy-

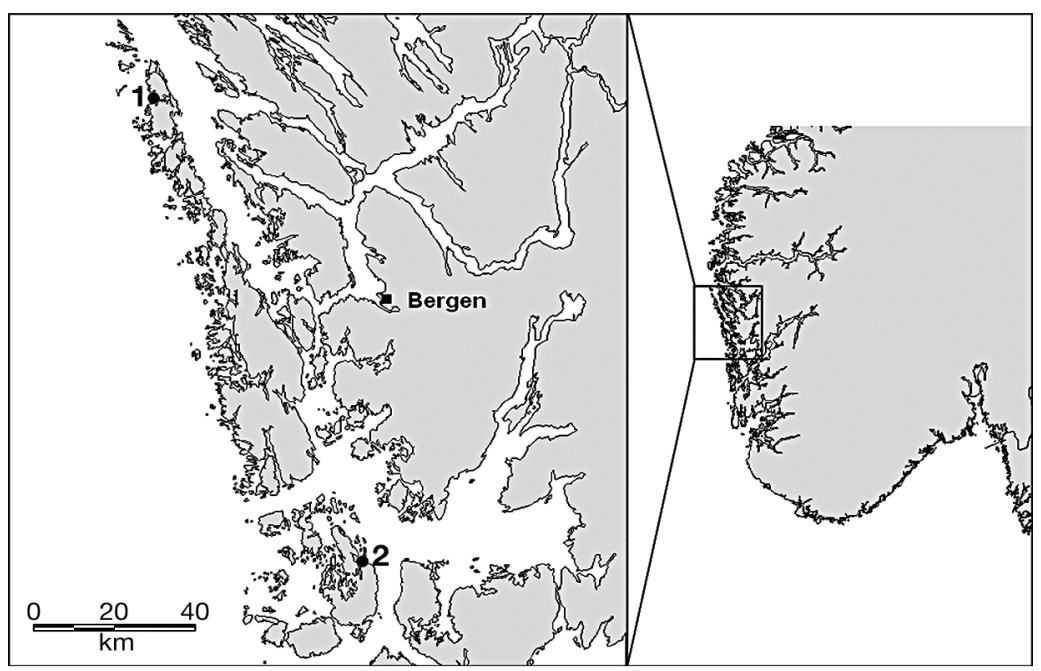

Fig. 1. West coast of Norway. 1: Parisvatn; 2: Austevoll. Broodfish were transported from Austevoll to Parisvatn prior to spawning drated in ethanol and embedded in paraffin. Sections of 3 to $5 \mu \mathrm{m}$ were cut on a microtome (Jung Biocut 2035) and mounted on glass slides. Histology slides were prepared by staining with haematoxylin and eosin, and IHC analyses were prepared by using primary antibody (Ø150) as described by Grotmol et al. (1999), with modifications by Sommerset \& Nerland (2004).

Bacteriology. Kidney tissue was streaked onto blood agar plates ( $5 \%$ ovine blood), with $0.5 \% \mathrm{NaCl}$, and marine agar (MA) plates (Difco), and was incubated for $7 \mathrm{~d}$ at $18^{\circ} \mathrm{C}$ (MA) and at $15^{\circ} \mathrm{C}$ (blood agar).

Real-time RT-PCR. RNA from tissue samples was extracted using Trizol (Invitrogen) and an RNAeasy kit (Qiagen) according to the manufacturer's instructions and stored at $-80^{\circ} \mathrm{C}$. Tissues sampled were analysed by 2 assays, both using nodavirus-specific primers and probes (Korsnes et al. 2005, Nerland et al. 2007). Heart tissues were also screened for the presence of infectious pancreatic necrosis virus (IPNV) as described by Watanabe et al. (2006) and kidney tissue for Francisella sp. as described by K. F. Ottem, A. Nylund, T. E. Isaken, E. Karlsbakk (unpubl. data). The real-time RTPCR assays utilised a TaqMan MGB probe (Applied Biosystems). Amplification was performed at the Institute of Marine Research (Bergen) for tissues sampled in August and at the PatoGen Analyse AS laboratory (Ålesund) for the sampling in September.

\section{RESULTS}

\section{Clinical signs and gross pathology}

A cumulated mortality in the cod Gadus morhua population at the growth site was estimated to reach $15 \%$. Fish showed general clinical signs of disease, such as loss of appetite and darkening of the skin. In addition, abnormal swimming behaviour was observed, consisting of looping or spiral swimming with belly-up and loss of coordination (Fig. 2). Necropsy revealed that the gastrointestinal tract was empty in all fish examined, and the swim bladder was distended to various degrees. The sampled fish were heterogeneous in size, weighing from 5 to $24 \mathrm{~g}$.

\section{Bacteriology}

Bacterial growth was observed on both MA and blood agar. The bacterial colonies tested positive for Listonella 


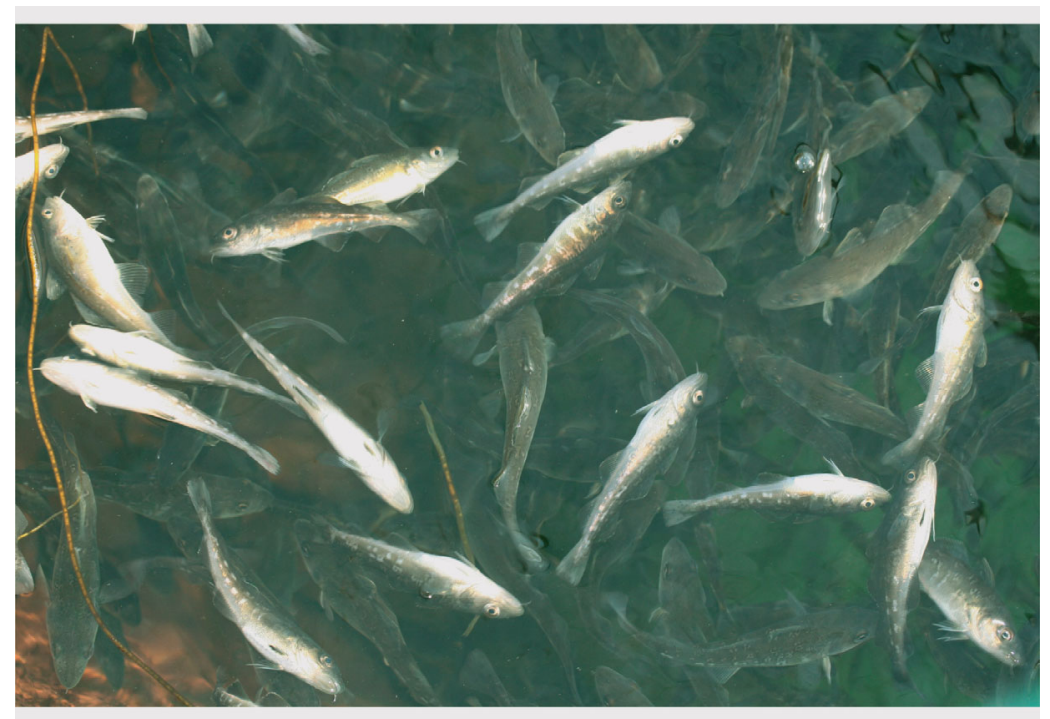

Fig. 2. Gadus morhua. Atlantic cod showing clinical signs of viral encephalopathy and retinopathy (VER). Infected fish show abnormal swimming behaviour, with looping and lack of coordination. Photo: Sonal Patel
(Starkey et al. 2001, Johnson et al. 2002). Nodavirus nucleic acid was detected by 2 real-time RT-PCR assays. The diagnosis was later confirmed by sampling for IHC, when pathological changes and detection of virus particles were observed. The National Veterinary Institute (Norway) also diagnosed VER in cod sampled at Parisvatn in August 2006, by observation of classical histopathological changes in the eye (retina) and the brain. They also detected nodavirus in affected fish by immunohistochemistry (published at www.vetinst.no). In summary, these findings suggest that the cod were suffering from VER, which contributed to the mortality observed.

The fish size in the sampled group was heterogeneous and varied from 5 to $25 \mathrm{~g}$, and mortality due to nodavirus in cod of these sizes has not been reported previously. In Scotland, Starkey et al. (2001)

(vibrio) anguillarum by the rapid agglutination test Mono-Va (Bionor).

\section{Immunohistochemistry}

Focal vacuolating encephalopathy and retinopathy was observed in the affected fish. Lesions were most pronounced in retina and brain, with vacuoles and focal necrosis. Immunolabelling revealed nodaviruspositive cells in both retina and brain for the primary antibody applied .

\section{Real-time RT-PCR}

All brain tissues examined were positive for nodavirus at the sampling in August. In September all examined tissues, including brain and retina, were positive for the virus, demonstrating a systemic infection. The tissues screened for IPNV and Francisella sp. were all negative.

\section{DISCUSSION AND CONCLUSIONS}

This is the first report of an outbreak of VER in farmed Atlantic cod Gadus morhua in Norway. This is also the first report on mortalities due to VER in cod exceeding $5 \mathrm{~g}$, whereby the majority of the fish in the affected population weighed from 5 to $10 \mathrm{~g}$ at the time of sampling. The clinical observations are consistent with other reports of nodavirus infections in cod reported that cod between 1.5 and $3.5 \mathrm{~g}$ in size suffered high mortality, reaching almost $100 \%$ after a few months. Johnson et al. (2002) reported high mortality in cod larva production in North America. The larger size of the cod juveniles at Parisvatn could explain why, in this case, only $15 \%$ mortality was observed. Nodavirus is reported to affect marine fish larvae primarily (Munday et al. 2002), but disease has also been reported in adult fish. In cold-water fish species, there is a report on clinical signs of VER and detection of nodavirus in adult Atlantic halibut Hippoglossus hippoglossus in Norway (Aspehaug et al. 1999). The mortality rate at Parisvatn was only estimated, as fish were also lost to cannibalism, bacterial infection and non-determined causes. Some mortality has always been observed in the cultivation of cod at Parisvatn (J. Petersen pers. obs), but the clinical signs and rate of mortality were not consistent with previously experienced outbreaks of vibriosis. When the seawater temperature increased (maximum at 18 to $19^{\circ} \mathrm{C}$ ), the rearing condition became suboptimal for cod and the risk of disease outbreak increased. In addition, the fish group was not graded to even the size composition within the group, which explains the size variation observed. The development of clinical signs and mortality in cod that were $>5 \mathrm{~g}$ is one distinct characteristic in this VER outbreak, and raises questions of possible variation in virulence in nodavirus isolates or genotypes. There has been observation of mortality in large cod in Norway, in fish ranging from 1 to $1.5 \mathrm{~kg}$ in weight, where clinical signs of VER and detection of nodavirus have been reported (authors' pers. obs.). The cod at Parisvatn were screened for known 
pathogens previously detected in aquaculture farms. This revealed only one bacterial pathogen, Listonella (vibrio) anguillarum, causing vibriosis in a number of fish species in Norway. Like many other marine fish species, young stages of cod are highly susceptible to vibriosis (Egidius 1987). Infections by $L$. anguillarum in cod are typical Gram-negative septicaemias, and the bacterium can typically be isolated from the head and kidney (Egidius \& Andersen 1984). Despite vaccination, outbreaks of vibriosis in cod farms are still common (Samuelsen et al. 2006). Whether this bacterium caused a primary or secondary infection is difficult to establish, but the clinical signs displayed by the fish did not correspond with other outbreaks of vibriosis in cod. We conclude that VER contributed to the mortal-
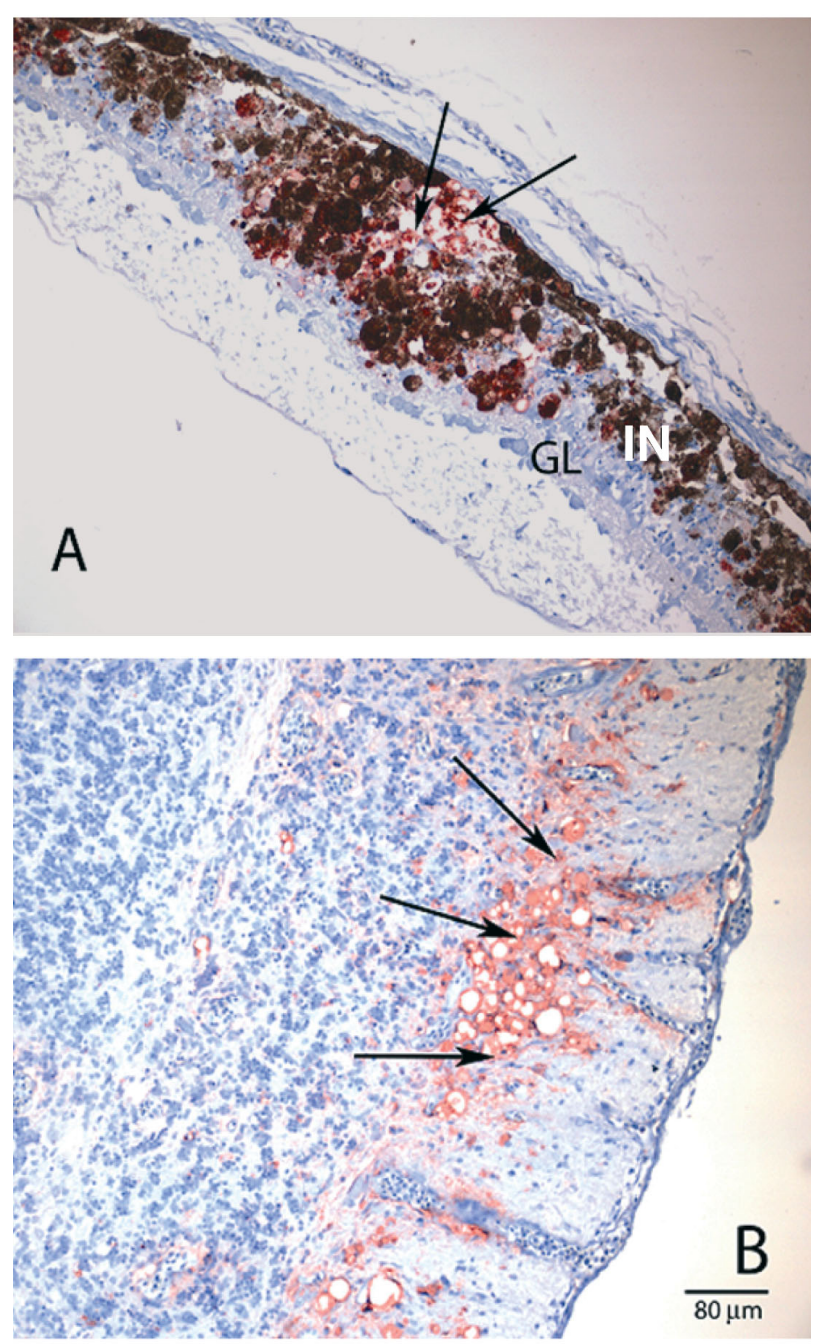

Fig. 3. Gadus morhua. (A) Immunolabelling of a section of retina (arrows). Focal lesions in the ganglion cell layer (GL) and inner nuclear layer (IN). (B) Section of brain. Staining of the nervous tissue with occasional foci of degeneration and vacuolization. Positive immunolabelling for nodavirus

(arrows) is seen as red staining in the tissue sections ity, based on the clinical and pathological signs and detection of nodavirus, and that the $L$. anguillarum infection most likely was secondary.

Both real-time PCR analyses demonstrated the presence of nodavirus nucleic acid in the diseased fish. All tissues examined were positive, suggesting a systemic infection, and support the clinical observations. The diagnosis was later confirmed by IHC in cod sampled in Parisvatn in March 2007, where classical pathological changes in the eye and brain and nodavirus particles were observed (Fig. 3).

In conclusion, our findings demonstrate the presence of nodavirus and VER disease in a Norwegian cod farm. Our conclusions also support the findings at The National Veterinary Institute. VER-associated mortality in cod as large as $24 \mathrm{~g}$ in weight is a major concern and has not been documented previously. Possible variation in virulence of nodavirus strains or genotypes should consequently be studied further.

Acknowledgement. The authors thank Elin Sørhus and Ingrid Uglenes Fiksdal at the Institute of Marine Research (IMR) and Magnus Devold at PatoGen Analyse AS for technical assistance. Hege Hellberg at the National Veterinary Institute in Bergen is thanked for correspondence on the official VER diagnosis given to the cod at Parisvatn. Vidar Wennevik at IMR is thanked for preparing Fig. 1. This study was financially supported by IMR.

\section{LITERATURE CITED}

Aspehaug V, Devold M, Nylund A (1999) The phylogenetic relationship of nervous necrosis virus from halibut (Hippoglossus hippoglossus). Bull Eur Assoc Fish Pathol 19: 196-202

Block B, Gravingen K, Larsen JL (1991) Encephalomyelitis among turbot associated with a picornavirus-like agent. Dis Aquat Org 10:65-70

Blom G, Otterå H, Svåsand T, Kristiansen TS, Serigstad B (1991) The relationship between feeding conditions and production of cod fry (Gadus morhua L.) in a semi-enclosed marine ecosystem in western Norway, illustrated by use of a consumption model. ICES Mar Sci Symp 192: 176-189

Bricknell IR, Bron JE, Bowden TJ (2006) Diseases of gadoid fish in cultivation: a review. ICES J Mar Sci 63:253-266

Egidius E (1987) Vibriosis: pathogenicity and pathology. A review. Aquaculture 67:15-28

Egidius E, Andersen K (1984) Disease problems in cod rearing. In: Dahl E, Danielsen E, Moksness E, Solemdal P (eds) The propagation of cod Gadus morhua L. Institute of Marine Research, Flødevigen Research Station, Arendal, p 761-769

Grotmol S, Totland GK, Kvellestad A, Fjell K, Olsen AB (1995) Mass mortality of larval and juvenile hatchery-reared halibut (Hippoglossus hippoglossus) associated with the presence of virus-like particles in the central nervous system and retina. Bull Eur Assoc Fish Pathol 15:176-180

Grotmol S, Totland GK, Thorud K, Hjeltnes BK (1997) Vacuolating encephalopathy and retinopathy associated with a nodavirus-like agent: a probable cause of mass mortality 
of cultured larval and juvenile Atlantic halibut Hippoglossus hippoglossus. Dis Aquat Org 29:85-97

Grotmol S, Bergh O, Totland GK (1999) Transmission of viral encephalopathy and retinopathy (VER) to yolk-sack larvae of the Atlantic halibut Hippoglossus hippoglossus: occurrence of nodavirus in various organs and a possible route of infection. Dis Aquat Org 36:95-106

Johansen R, Sommerset I, Torud B, Korsnes K, Hjortaas MJ, Nilsen F, Nerland AH, Dannevig BH (2004) Characterization of nodavirus and viral encephalopathy and retinopathy in farmed turbot, Scophthalmus maximus (L.). J Fish Dis 27:591-601

Johnson SC, Sperker SA, Leggiadro CT, Groman DB, Griffiths SG, Ritchie RJ, Cook MD, Cusack RR (2002) Identification and characterization of a piscine neuropathy and nodavirus from juvenile Atlantic cod from the Atlantic coast of North America. J Aquat Anim Health 14:124-133

Kjesbu OS, Taranger GL, Trippel EA (2006) Gadoid mariculture: development and future challenges. Introduction. ICES J Mar Sci 63:187-191

Korsnes K, Devold M, Nerland A, Nylund A (2005) Viral encephalopathy and retinopathy (VER) in Atlantic salmon Salmo salar after intreperitoneal challenge with a nodavirus from Atlantic halibut Hippoglossus hippoglossus. Dis Aquat Org 68:7-15

Mori KI, Nakai T, Muroga K, Arimoto M, Mushiake K, Furusawa I (1992) Properties of a new virus belonging to Nodaviridae found in larval striped jack (Pseudocaranx Dentex) with nervous necrosis. Virology 187(1):268-371

Munday BL, Kwang J, Moody N (2002) Betanodavirus infections of teleost fish: a review. J Fish Dis 25:127-142

Nerland AH, Skaar C, Eriksen TB, Bleie H (2007) Detection of

Editorial responsibility: Mark Crane,

Geelong, Victoria, Australia nodavirus in seawater from rearing facilities for Atlantic halibut Hippoglossus hippoglossus larvae. Dis Aquat Org 73:201-205

Nishizawa T, Mori KI, Furuhasi M, Nakai T, Muroga K, Furusawa I, Muroga K (1995) Comparison of the coat protein genes of 5 fish nodaviruses, the causative agents of viral nervous necrosis in marine fish. J Gen Virol 76: 1563-1569

Nylund A, Ottem KF, Watanabe K, Karlsbakk E, Krossøy B (2006) Francisella sp. (Family Francisellaceae) causing mortality in Norwegian cod (Gadus morhua) farming. Arch Microbiol 185:383-392

Olsen AB, Mikalsen J, Rode M, Alfjorden A, Hoel E, StraumLie K, Haldorsen R, Colquhoun D (2006) A novel systemic granulomatous inflammatory disease in farmed Atlantic cod, Gadus morhua L., associated with a bacterium belonging to the genus Francisella. J Fish Dis 29:307-311

Samuelsen OB, Nerland AH, Jørgensen T, Schrøder MB, Svåsand T, Bergh Ø (2006) Viral and bacterial diseases of Atlantic cod Gadus morhua, their prophylaxis and treatment: a review. Dis Aquat Org 71:239-254

Sommerset I, Nerland AH (2004) Complete sequence of RNA1 and subgenomic RNA3 of Atlantic halibut nodavirus (AHNV). Dis Aquat Org 58:117-125

Starkey WG, Ireland JH, Muir KF, Jenkins ME, Roy WJ, Richards RH, Ferguson HW (2001) Nodavirus infection in Atlantic cod and Dover sole in the UK. Vet Rec 149: 179-181

Watanabe K, Karlsen M, Devold M, Isdal E, Litlabø A, Nylund A (2006) Virus-like particles associated with heart and skeletal muscle inflammation (HSMI). Dis Aquat Org 70: 183-192

Submitted: March 10, 2007; Accepted: June 26, 2007

Proofs received from author(s): September 6, 2007 